\title{
IMPLEMENTASI REKRUITMEN BINTARA POLRI DI WILAYAH KEPOLISAN RESORT BANYUMAS BERDASARKAN UNDANG-UNDANG NOMOR 2 TAHUN 2002 TENTANG KEPOLISIAN NEGARA REPUBLIK INDONESIA Oleh: Donny Ramadita Pradana ${ }^{1}$
}

\begin{abstract}
The selection of candidates for the National Police in the recruitment process as an effort to select the right people in guarding the National Police Organization can be analogous to the process of selecting food. If you choose the wrong food and it turns out the choice contains seeds of disease, it will have a negative impact on your own health condition. Erroneous personnel selection will have an influence on the organization, because it will disrupt the activities of the organization which will only deal with personnel who are problematic, incompetent and unable to face the demands of an increasingly complex society.

The implementation of the recruitment of the National Police Center in the Banyumas Resort Police Region in 2018 can be carried out properly in accordance with the provisions of the 2016 National Police Chief Regulation of the Republic of Indonesia concerning the Acceptance of Candidates for members of the Indonesian National Police. Keywords : Implementation of Recruitment, Police Officers, Police of Banyumas Resort.
\end{abstract}

\begin{abstract}
ABSTRAK
Seleksi calon Polri dalam proses rekruitmen sebagai upaya memilih orang-orang yang tepat dalam pengawakan Organisasi Polri dapat dianalogikan dengan proses pemilihan makanan. Apabila salah memilih makanan dan ternyata pilihannya mengandung bibit penyakit, maka akan berdampak buruk bagi kondisi kesehatan tubuh sendiri. Kesalahan pemilihan personil akan membawa pengaruh kepada organisasi, karena akan menganggu kegiatan organisasi yang nantinya hanya akan mengurusi personil yang bermasalah, tidak cakap dan tidak mampu menghadapi tuntutan masyarakat yang semakin kompleks.

Implementasi rekruitmen Bintara Polri di Wilayah Kepolisian Resort Banyumas tahun 2018 dapat dilaksanakan dengan baik sesuai dengan yang diatur dalam Peraturan Kepala Kepolisian Negara Republik Indonesia Tahun 2016 Tentang Penerimaan Calon anggota Kepolisian Negara republik Indonesia.

Katakunci : Bintara Polisi, Implementasi Rekruitmen, ,Kepolisian Resort Banyumas
\end{abstract}

\footnotetext{
${ }^{1}$ Pegawai BNNK, Banyumas, donnyramadita@gmail.com
} 


\section{A. Pendahuluan}

Program revitalisasi Polri menuju pelayanan prima guna meningkatkan kepercayaan masyarakat yang telah disampaikan pada uji kelayakan dan kepatutan (fit and proper test) di depan Komisi III DPR RI, berisi kerangka makro program (road map) revitalisasi dan 10 (sepuluh) program prioritas. Pemahaman hal tersebut dikarenakan Revitalisasi mengandung arti menjadikan sesuatu menjadi vital, bermanfaat atau penting kembali dengan memberikan sentuhan-sentuhan baru. Revitalisasi dalam tubuh Polri merupakan langkah untuk menghidupkan, membangun dan memberdayakan kembali nilai-nilai kemampuan yang telah dimiliki oleh Polri disegala bidang, yang selama ini belum dapat diwujudkan secara maksimal dalam menghadapi tantangan tugas Polri. ${ }^{2}$

Kepolisian Republik Indonesia ditegaskan dalam Undang-undang Nomor 2 Tahun 2002 tentang Kepolisian Negara Republik Indonesia sebagai berikut:

1. Kepolisian adalah segala halinwal yang berkaitan dengan fungsi dan lembaga polisi sesuai dengan peraturan perundangundangan.

2. Anggota Kepolisian Negara Republik Indonesia adalah

2 Pedoman Penjabaran Program Revitalisasi Polri Menuju Pelayanan Prima Guna Meningkatkan Kepercayaan Masyarakat https://ferli1982.wordpress.com/2013/01/08/p edoman-penjabaran-program-revitalisasipolri-menuju-pelayanan-prima-gunameningkatkan-kepercayaan-masyarakat/ pegawai negeri pada Kepolisian Negara Republik Indonesia.

3. Pejabat Kepolisian Negara Republik Indonesia adalah anggota Kepolisian Negara Republik Indonesia yang berdasarkan undang-undang memiliki wewenang umum Kepolisian.

Kapolri, telah menetapkan program "Promoter" yaitu Profesional, Modern dan Terpercaya. Penjabaran "Promoter" tersebut yaitu Profesional: Meningkatkan kompetensi SDM Polri yang semakin berkualitas melalui peningkatan kapasitas pendidikan dan pelatihan, serta melakukan pola-pola pemolisian berdasarkan prosedur baku yang sudah dipahami, dilaksanakan, dan dapat diukur keberhasilannya. Modern: Melakukan modernisasi dalam layanan publik yang didukung teknologi sehingga semakin mudah dan cepat diakses oleh masyarakat, termasuk pemenuhan kebutuhan Almatsus dan Alpakam yang makin modern. Terpercaya: Melakukan reformasi internal menuju Polri yang bersih dan bebas dari KKN, guna terwujudnya penegakan hukum yang obyektif, transparan, akuntabel, dan berkeadilan.

Keberhasilan pelaksanaan reformasi birokrasi Polri perlu didukung dengan manajemen sumberdaya manusia yang tepat. Sumberdaya yang dimiliki organisasi berupa mesin, modal, sistem, dan manusia. Organisasi akan dapat beroperasi apabila sumber daya yang dimilikinya dapat digerakkan dengan baik. Manusia merupakan sumber daya utama yang ada dalam 
67|Jurnal I d e a H u k m

Vol. $6 \mathrm{No}$. $1 \mathrm{M}$ aret 2020

Magister Hukum Universitas Jenderal Soedirman

organisasi, karena tanpa keberadaan manusia dalam organisasi tersebut, maka sumber daya lainnya yang dimiliki oleh organisasi tersebut tidak akan berarti.

Secara universal hingga kini di negara-negara demokratis terdapat tiga sistem Kepolisian yang digunakan, yaitu: 3

1. Fragmented System of Policing (Sistem kepolisian terpisah atau berdiri sendiri)

Disebut juga sistem Desentralisasi yang ekstrim atau tanpa sistem. Di mana adanya kekhawatiran terhadap penyalahgunaan dari suatu organisasi polisi yang otonom dan dilakukan pembatasan kewenangan polisi. Sistem ini dianut oleh Negara Belgia, Kanada, Belanda, Switzerland, Amerika Serikat.

2. Centralized System of Policing (Sistem Kepolisian Terpusat)

Berada langsung di bawah kendali pemerintah. Negaranegara yang menganut sistem ini adalah Perancis, Italia, Finlandia, Israel, Thailand, Taiwan, Irlandia, Denmark, Swedia, dan Indonesia.

3. Integrated System of Policing (Sistem Kepolisian Terpadu)

3

http://www.scribd.com/doc/25062921/Perban dingan-Sistem-Kepolisian- Amerika-SerikatJepang-Indonesia..
Disebut juga sistem

desentralisasi moderat atau kombinasi atau kompromi, merupakan sistem kontrol yang dilakukan pemerintah pusat dan daerah agar terhindar dari penyalahgunaan organisasi Polisi Nasional serta efektif, efisien, dan seragam dalam pelayanan. Negara-negara yang menganut sistem ini adalah Jepang, Australia, Brasilia, Inggris.

Indonesia yang menerapkan Centralized System of Policing (Sistem Kepolisian Terpusat), sehingga proses rekruitmen juga dilakukan secara terpusat, artinya kebijakan penerimaan anggota Polri diatur okeh pemerintah pusat. Daerah hanya menjadi pelaksana rekruitmen saja. Sejak hari Senin tanggal 26 Maret Tahun 2018, Kepolisian Republik Indonesia (Polri) sudah membuka penerimaan anggota kepolisian. Penerimaan anggota baru ini meliputi delapan jenis seleksi, yaitu Taruna Akpol, Bintara Polri, Tamtama Polri, Bintara TI, Bintara Musik, Bintara Kimia, Bintara Penerbangan, dan Bintara Pelayaran. Sementara, untuk Sekolah Inspektur Polisi Sumber Sarjana (SIPSS) sudah ditutup sejak 1 Februari 2018. Pendaftaran dan seleksi anggota Polri ini tanpa dipungut biaya alias gratis. 


\section{B. Metode Penelitian}

Metode Pendekatan yang digunakan adalah Yuridis Sosiologis, Spesifikasi penelitian Deskriptif Analisis. Sumber Data yang digunakan adalah: a. Bahan Hukum Primer; b. Bahan Hukum Sekunder; c. Bahan Hukum Tersier dengan metode Analisis Data Deduktif.

\section{Hasil Penelitian dan Pembahasan} 1. Implementasi Rekruitmen Bintara Polri di Wilayah Kepolisan Resort Banyumas

Proses rekruitmen anggota Bintara Polri tentulah harus dalam wadah keadilan yang memberikan kesempatan lepada setiap warga negara sesuai dengan persyaratan yang telah ditentukan untuk bisa ikut berkompetisi dan mendapatkan penilaian yang objektif. Keadilan dalam proses rekruitmen akan mendukung terwujudnya birokrasi kepolisian yang profesional sesuai dengan cita good governance.

Dalam kehidupan kenegaraan modern, birokrasi semakin menjadi perangkat sentral untuk memenuhi kepentingan masyarakat. Pada abad kedua puluh satu ini birokrasi menjadi demikian penting, dan masyarakat hanya akan mendapat pelayanan publik secara memuaskan jika itu diselenggarakan melalui birokrasi modern. ${ }^{4}$

Kondisi tersebut menuntut untuk diperolehnya Bintara Polri yang sesuai dengan kebutuhan. Calon Bintara Polri mendapatkan kesempatan untuk mengikuti setiap proses dengan baik, sehingga akan diperoleh Bintara Polri yang profesional nantinya dalam menjalankan tugasnya. Terpilihnya Bintara Polri yang profesional sangat mendukung untuk mendukung kegiatan pembangunan, karena terciptanya ketertiban dan keamanan dalam masyarakat.

Fungsi hukum sebagai sarana pembaharuan masyarakat berkorelasi dengan konsep politik hukum (rechtspolitiek) yang dalam referensi anglosaxis dikenal dengan Kebijaksanan Hukum (Legal Policy Theory). ${ }^{5}$ Politik hukum sebagai suatu pernyataan kehendak penguasa negara mengenai hukum yang berlaku di wilayahnya, dan mengenai arah perkembangan hukum yang dibangun. $^{6}$

Dalam rangka mewujudkan Kepolisian Negara Republik Indonesia yang profesional,

\footnotetext{
${ }^{4}$ Wahyudi Kumorotomo, 1992, Etika

Administrasi Negara, Rajawali Pers, Jakarta, hlm. 71

5 Imam Syaukani \& A.Ahsin Thohari, 2004.Dasar-Dasar Politik Hukum, Jakarta, RajaGrafindo Persada, hlm. 19

${ }^{6}$ Yudha Bhakti Ardhiwisastra, 1999. Imunitas Kedaulatan Negara Di Forum Pengadilan Asing, Bandung, Alumni, hlm. 41
} 
69 J u rnal I d e a H u k m

Vol. $6 \mathrm{No}$. $1 \mathrm{Maret} 2020$

Magister Hukum Universitas Jenderal Soedirman

bermoral dan modern sebagai

pemelihara keamanan dan

ketertiban masyarakat, penegak

hukum serta pelindung, pengayom

dan pelayan masyarakat,

diperlukan sumber daya manusia

Kepolisian Negara Republik

Indonesia yang unggul dan

berkualitas. Untuk mendapatkan

sumber daya manusia Kepolisian

Negara Republik Indonesia yang

unggul dan berkualitas, diperlukan

sistem penerimaan calon anggota

Kepolisian Negara Republik

Indonesia yang dilaksanakan

secara bersih, transparan,

akuntabel, dan humanis.

Pasal 1 angka 4 Peraturan

Kepala Kepolisian Negara Republik

Indonesia Nomor 10 Tahun 2016

Tentang Penerimaan Calon

Anggota Kepolisian Negara

Republik Indonesia menegaskan

bahwa Penerimaan Calon Anggota

Polri adalah rangkaian kegiatan

seleksi penerimaan yang diikuti

oleh calon anggota Polri.

Selanjutnya disebutkan pada Pasal

2 bahwa prinsip penerimaan Calon

Anggota Polri, meliputi:

a. bersih, yaitu Penerimaan Calon Anggota Polri dilakukan secara obyektif, jujur, adil dan bebas dari Korupsi, Kolusi dan Nepotisme;

b. transparan, yaitu Penerimaan Calon Anggota Polri dilaksanakan secara terbuka dengan pengawasan pihak Internal, eksternal dan membuka akses kepada publik;

c. akuntabel, yaitu proses dan hasil Penerimaan Calon Anggota
Polri dapat dipertanggungjawabkan; dan

d. humanis, yaitu Penerimaan Calon Anggota Polri dilakukan dengan sikap ramah, santun, dan menjunjung tinggi nilai hak asasi manusia.

Pasal 6 menentukan bahwa penerimaan calon Bintara Polri dilaksanakan untuk membentuk Bintara Polri dengan pangkat Brigadir Polisi Dua yang memiliki pengetahuan dan kemampuan dasar Kepolisian, ketangguhan, sikap dan perilaku terpuji sebagai pelaksana utama tugas Polri. Adapun persyaratan penerimaan diatur dalam Pasal 8 sebagai berikut:

(1) Dalam Penerimaan Calon Anggota Polri, sekurangkurangnya memenuhi persyaratan:

a. Warga Negara Indonesia;

b. beriman dan bertakwa kepada Tuhan Yang Maha Esa;

c. setia kepada Negara

Kesatuan Republik

Indonesia berdasarkan

Pancasila dan Undang-

Undang Dasar Negara

Republik Indonesia Tahun

1945;

d. berpendidikan paling rendah Sekolah Menengah Umum atau yang sederajat;

e. berumur paling rendah 18 (delapan belas) tahun pada 
saat diangkat menjadi anggota Polri;

f. sehat jasmani dan rohani;

g. tidak pernah dipidana dan/atau tidak sedang menjalani proses pemeriksaan karena melakukan suatu kejahatan; dan

h. berwibawa, jujur, adil dan berkelakuan tidak tercela.

(2) Selain persyaratan sebagaimana dimaksud pada ayat (1), dalam penerimaan anggota Polri dapat ditambah persyaratan lain sesuai kebutuhan yang ditetapkan dengan Keputusan Kapolri.

Tahapan penerimaan Calon Anggota Polri diatur dalam Pasal 10 sampai Pasal 14 yang kegiatan:
a. kampanye;
b. pendaftaran;

c. seleksi; dan

d. sidang penetapan

Informasi tentang proses rekruitmen diperoleh dari hasil wawancara dengan informan yaitu AKBP Edy Santosa, S.Sos., M.Si. dan Kompol Mugiman, SH., $\mathrm{MH}$. Informasi yang diperoleh dari AKBP Edy Santosa, S.Sos., M.Si, bahwa kebutuhan bintara Polri saat ini dan kedepan sangat dibutuhkan karena Bintara Polri merupakan garda yang paling depan dalam pelaksanaan tugas. maka saat ini dalam perekrutannya dibutuhkan calon Bintara yang mempunyai wawasan dan berpendidikan minimal SLTA sederajat bahkan D3 maupun S1. Minat masyarakat sangat tinggi untuk menjadi bintara Polri.

Dasar hukumnya rekruitmen Bintara Polri adalah Perkap Kapolri no 10 tahun 2016 tanggal 14 Nopember Tahun 2016. Kepanitiaan di daerah dituangkan oleh surat perintah Kapolres dan untuk tingkat Polda oleh Kapolda. Tahapan proses rekruitmen diatur dalam Perkap Kapolri no 10 tahun 2016 Bab 3 Pasal 10.

Pihak-pihak yang terlibat dalam proses rekruitmen di wilayah Polres Banyumas adalah pemda setempat, Dinas Pendidikan, Tokoh Masyarakat, Tokoh Agama, dan Tokoh Pemuda, Radio Swasta dan Koran Daerah. Upaya yang dilakukan oleh masyarakat untuk rekruitmen adalah menghendaki transparan dan mengetahui setiap tahapan seleksi. Tahapan proses rekruitmen Bintara Polri di tingkat Polres Banyumas adalah melalui tahapan awal yaitu soaialisasi, seleksi postur tubuh, dan seleksi administrasi tentang keabsahan ijazah yang melibatkan Dinas Pendidikan.

Kelemahan yang ada dalam rekruitmen di Polres Banyumas masih banyak masyarakat yang kurang mendapat sosialisasi tentang proses rekruitmen. Oleh 
karena itu, sosialisasi yang sudah dilaksanakan hendaknya dapat ditingkatkan di tahun-tahun yang akan datang dengan memberikan selebaran/leaflet di setiap institusi pendidikan mulai pendidikan menengah sampai di pendidikan tinggi.

$$
\text { Lembaga Swadaya }
$$

Kemasyarakatan terlibat dalam rekruitmen Bintara Polri dalam penandatanganan fakta integritas. Namun demikian, memang masih terdapat keraguan masyarakat tentang transparansi dalam proses rekruitmen Bintara Polri. Pihak kepolisian sudah berusaha menerapkan sistem BETAH yaitu Bersih, Transparan, Akuntabel dan Humanis. Pengawasan internal dan eksternal sudah melaksanakan yang berjenjang yang sangat ketat.

Adapun informasi yang diperoleh dari wawancara dengan Kompol Mugiman, $\mathrm{SH}$., MH, bahwa persiapan rekruitmen mengadakan sosialisasi terkait rekruitmen secara terpadu, Bintara Akpol, dengan sasaran ke sekolah-sekolah seperti SMA dan SMK serta juga ke masyarakat atau melalui kapolsek, dengan media brosur. Tujuan dari sosialisasi ini adalah untuk mendapatkan animo cabang anggota POLRI untuk mendapatkan anggota POLRI yang berkualitas dan unggul.

2. Kendala dan solusi dalam implementasi rekruitmen

\section{Bintara Polri di Wilayah} Kepolisan Resort Banyumas

Proses rekruitmen yang dilandasi konsep keadilan menuju terciptanya good governance dalam mendukung kegiatan pembangunan tentulah tidak selalu dapat berjalan sesuai dengan yang diharapkan. Pelaksanaan fungsi hukum oleh negara dalam mensejahterakan rakyat adalah tugas (sesuatu yang wajib dikerjakan), yang merupakan tanggung jawab negara dalam mencapai tujuan negara secara konkrit. Tujuan negara menurut John Locke, adalah menjamin hak asasi manusia, yang dapat dikaitkan dengan hak memperoleh perlindungan kesehatan melalui pengendalian produk tembakau terhadap kesehatan. Negara dianggap gagal apabila tidak dapat menjalankan fungsinya dalam mencapai tujuan negara, yaitu menciptakan kebahagiaan secara umum baik ditinjau dari sisi ekonomi maupun sosial, juga budaya, termasuk didalamnya hak memperoleh keadilan dalam pengendalian produk tembakau terhadap kesehatan. ${ }^{7}$

Dalam proses rekruitmen, sarana dan prasarana menempati posisi penting yang akan mendukung kegiatan rekuitmen

\footnotetext{
${ }^{7}$ Amarta Sein, 2000, Welfare State, Editor, Wiliam Huffman, USA.Harvard University
} Press, Boston, Massatchusetts hlm.123. 
dapat berjalan dengan baik mulai dari proses sosialisasi sampai dengan tahap penentuan akhir. Kendala yang dihadapi dalam proses rekruitmen untuk mendapatkan Bintara Polri yang profesional yaitu masalah anggaran terkait dengan fasilitas atau sarana fisik yang diperlukan dalam pemeriksaan fisik. Upaya tersebut diatasi dengan bekerjasama dengan insitusi kesehatan yang ada di daerah. Pemeriksaan dilaksanakan terlebih dahulu, baru kemudian dibayarkan dana. Sifatnya sebagai membantu panitia daerah.

Persoalan lain adalah tentang urut tinggi badan. Terdapat mekanisme adanya pengukuran lagi di tingkat POLDA dan adanya pengukuran ulang. (kerjasama dengan dinas kependudukan dan pendidikan). Tidak memenuhi persyaratan akan ditolak dari pihak panitia dan bila berkesempatan untuk mendaftar lagi.

Calon Bintara diminta untuk jangan terpengaruh oleh adanya calo atau pihak lain yang menerima adanya calo. Pihak panitia juga sudah menerapkan Zona Integritas yaitu wilayah bebas dari korupsi, wilayah banjarsari bersih dan melayani. Biro SDM PODA Jateng juga sudah dibangun zona integritas. Waktu pendidikan untuk Bintara masih 7 bulan, seperti aturan yang lama. Jika ada kegiatan kriminal akan dilakukan penindakan atau pemrosesan. Komitmen dari panitia itu sendiri dan integritas untuk melaksanakan tugas dengan baik dan benar.

Penerimaan Bintara Polri sebagai bagian dari penyediaan SDM Polri bertujuan untuk mencapai sasaran kekuatan dengan memilih warga Negara yang berkualitas untuk menjadi anggota Polri yang nantinya diharapkan mampu berperan sebagai pengemban tugas kepolisian dalam memberikan pelayanan, perlindungan dan pengayoman kepada masyarakat secara professional, bermoral dan modern. Olah karenanya setiap calon anggota Polri dituntut memiliki kualitas yang dipersyaratkan, baik yang menyangkut dengan aspek mental kepribadian, inteligensia, maupun kesehatan serta kesamaptaan jasmani. Prinsip BETAH dilaksanakan sebagai upaya untuk dapat menjaring Bintara Polri yang profesional yaitu:

a. Bersih, yaitu proses penerimaan calon Bintara Polri dilakukan secara obyektif, jujur, adil dan bebas dari Korupsi, Kolusi dan Nipotisme (KKN).

b. Transparan, yaitu semua tahapan penerimaan dilaksanakan secara terbuka dengan pengawasan pihak 
73 J u rna 1 I d e a $\mathrm{Hukum}$

Vol. $6 \mathrm{No} .1 \mathrm{Maret} 2020$

Magister Hukum Universitas Jenderal Soedirman

internal, eksternal dan membuka akses kepada Publik.

c. Akuntabel, yaitu proses dan hasil penerimaan calon Bintara Polri dapat dipertanggungjawabkan.

d. Humanis, yaitu mempelakukan calon Bintara Polri secara manusiawi.

Sosialisasi pendaftaran Bintara Polri yang sudah dilakukan berbagai media tersebut belum seluruhnya dapat dinikmati atau diketahui secara luas oleh masyarakat, sebagaimana disampaikan oleh informan. Sehingga hal ini dapat menyebabkan masyarakat masih belum sepenuhnya dapat menerima informasi secara utuh tentang proses rekruitmen Bintara Polri.

Himbauan untuk jangan terpengaruh terhadap adanya calo yang menjanjikan dapat meloloskan calon Bintara dengan sejumlah uang, masih belum dapat direspon sepenuhnya. Kondisi tersebut tentu saja tidak sepenuhnya dapat disalahkan pada pihak panitia saja, namun dari masyarakat sendiri yang belum aktif dalam mengakses informasi yang sudah banyak di informasikan melalui berbagai media massa.

Program 123 Clear and Clean merupakan program Polri yang disajikan dalam bentuk kampanye untuk mensosialisasikan pendaftaran atau penerimaan anggota Polri dan meningkatkan animo masyarakat untuk mendaftarkan diri menjadi anggota Polri baik dari sumber perwira, bintara maupun tamtama. Melalui program 123 Clear and Clean, Polri membuktikan janjinya untuk bersihbersih anggotanya yang nakal karena "main uang" dalam proses penerimaan anggota baru polisi dan akan dikenakan sanksi yang berat. Markas Besar Kepolisian RI tidak main-main untuk membersihkan rekrutmen anggota Polri dari praktik suap dan pungutan liar.

Polri tidak segan-segan untuk memberikan sanksi tegas kepada anggota yang terlibat pungli dan suap. Sosialisasi Program 123 Clear and Clean serentak dilaksanakan di tingkat Polres seluruh Indonesia. Untuk pelaksanaan dan prosesi kampanye Sosialisasi Program 123 Clear and Clean Polri menyerahkan kepada tiap-tiap Polres di seluruh Indonesia untuk berkreasi sekreatifitas mungkin.

Keberadaan berbagai media cetak dan media sosial, sehingga seluruh masyarakat dapat dengan mudah mengakses berbagai informasi terkait dengan Program 123 Clear and Clean yang diharapkan dapat mendorong masyarakat secara perlahan untuk mendapatkan informasi terkait 


$\begin{array}{ll}\begin{array}{l}\text { dengan transparansi proses } \\ \text { rekruitmen Bintara Polri. }\end{array} & \begin{array}{l}\text { yang baik. Namun demikian, untuk } \\ \text { ke depan, proses rekruitmen akan }\end{array} \\ \text { Tahun 2018, SPN } & \begin{array}{l}\text { lebih baik jika dapat dilakukan di } \\ \text { satu tempat, sehingga lebih efisien }\end{array} \\ \begin{array}{l}\text { Purwokerto hanya menerima } 320 \\ \text { calon bintara yang diseleksi dari }\end{array} & \begin{array}{l}\text { dan efektif serta memungkinkan } \\ \text { pendaftar sebanyak } 684 \text { orang. }\end{array} \\ \text { Jumlah itu berkurang separuh lebih } & \text { diperoleh hasil yang optimal. } \\ \text { dari calon bintara pada } 2017 \text { yang } & \text { dan Penandatanganan Pakta } \\ \text { mencapai } 750 \text { orang. Menurut } & \text { Integritas menjadi bagian penting } \\ \text { Kapolda Jawa Tengah Irjen Pol } & \text { dalam rangka penerimaan Bintara } \\ \text { Condro Kirono, berkurangnya calon } & \text { Polri Terpadu yang dilaksanakan } \\ \text { bintara ini karena Mabes Polri lebih } & \text { dengan tujuan memberikan } \\ \text { memprioritaskan pengisian } & \text { komitmen kepada masyarakat } \\ \text { personel polda-polda yang baru } & \text { bahwa proses rekrutmen atau } \\ \text { terbentuk khususnya di luar Jawa, } & \text { penerimaan anggota Polri } \\ \text { seperti di Papua Barat. }{ }^{8} & \text { diselenggarakan secara bersih, } \\ \text { Proses rekruitmen dari tahun } & \text { transparan, akuntabel dan humanis } \\ \text { tahun akan menghadapi } & \text { (BETAH), serta profesional dan } \\ \text { tantangan jaman, terkait dengan } & \text { terpercaya (Promoter). }\end{array}$
perkembangan ilmu dan teknologi, sehingga hanya putra dan putri terbaiklah yang seharusnya dapat terjaring untuk selanjutnya diberikan pendidikan yang terbaik. Input Polri yang baik hanya dapat diperoleh dari proses rekruitmen yang baik pula. Proses rekruitmen belum dapat dilakukan secara mandiri, karena masih harus bekerjasama dengan institusi lain.

Permasalahan anggaran dalam proses rekruitmen yang diatasi dengan cara bekerjasama dengan insitusi kesehatan yang ada di daerah, merupakan langkah

\footnotetext{
${ }^{8}$ Pendaftar Calon Polisi di Polda Jateng Menyusut, Ini Penyebabnya https://www.inews.id/daerah/jateng/206869/p endaftar-calon-polisi-di-polda-jatengmenyusut-ini-penyebabnya
}

\section{Penutup}

\section{Kesimpulan}

Berdasarkan hasil penelitian dan pembahasan dapat diambil kesimpulan sebagai berikut:

a. Implementasi rekruitmen Bintara Polri di Wilayah Kepolisan Resort Banyumas tahun 2018 dapat dilaksanakan dengan baik sesuai dengan Undang-Undang Nomor 2 Tahun 2002 Tentang Kepolisian Negara Republik Indonesia. Proses rekruitmen Bintara Polri meliputi tahapan pemeriksaan administrasi, 


$\begin{array}{lrlr}\text { pemeriksaan } & \text { kesehatan, } & \text { elemen di } & \text { kepolisian } \\ \text { pemeriksaan } & \text { psikologi, } & \text { termasuk } & \text { intitusi } \\ \text { Penelusuran } & \text { Mental } & \text { pemerintah } & \text { maupun } \\ \text { Kepribadian, } & \text { pengujian } & \text { lembaga } & \text { swadaya } \\ \text { akademik, } & \text { pengujian } & \text { masyarakat (LSM). }\end{array}$

kemampuan jasmani dan pemeriksaan

anthropometrik dan pemeriksaan penampilan oleh panitia pusat.

b. Kendala yang dihadapi dalam proses rekruitmen Bintara Polri adalah masalah anggaran, terkait dengan fasilitas atau sarana fisik yang diperlukan dalam pemeriksaan fisik sehingga perlu adanya kerjasama dengan institusi kesehatan yang ada di daerah. Permasalahan lain terkait dengan minimnya pengetahuan masyarakat tentang proses rekruitmen. Upaya yang dilakukan oleh Polri adalah dengan menerapkan Program 123 Clear and Clean dan diselenggarakan dengan Bersih, Transparan, Akuntabel Dan Humanis (BETAH) serta adanya sistem pengawasan internal dan eksternal secara ketat yang melibatkan berbagai

\section{Saran}

Saran-saran yang dapat diberikan terkait dengan kesimpulan penelitian sebagai berikut:

$\begin{array}{lr}\text { a. } & \text { Anggaran proses } \\ \text { rekruitmen } & \text { perlu }\end{array}$ disediakan sesuai dengan kebutuhan yang memungkinkan kegiatan rekruitmen dapat berjalan dengan baik dan jumlah kuota di semua wilayah Polda merata.

b. Informasi tentang Bintara Polri yang berasal dari keluarga yang tidak mampu perlu dipublikasikan untuk dapat memberikan informasi tentang transparansi proses rekruitmen Bintara Polri. Himbauan kepada masyarakat melalui berbagai media massa agar masyarakat tidak terpengaruh adanya calo yang menjanjikan dapat meloloskan dalam proses seleksi Bintara Polri. 


\section{DAFTAR PUSTAKA}

Abdulkadir Muhammad. 2001. Etika Profesi Hukum. Citra Aditya. Bandung

Anonim.

http://www.scribd.com/doc/2506292 1/Perbandingan-Sistem-KepolisianAmerika-Serikat-Jepang-Indonesia

Raharjo, Satjipto 1986, Hukum dan Perubahan Sosial, Suatu Tinjauan Teoritis, Suatu Tinjauan Teoritis Serta Pengalaman-Pengalaman di Indonesia, Bandung: Alumni.

Wahab, S. A. 2011. Analisis Kebijaksanaan dari Formulasi ke Implementasi Kebijaksanaan Negara. Bina Aksara : Jakarta.

Wibawa, S., 2012. Evaluasi Kebijakan Publik. Raja Grafindo Persada : Jakarta. 